\title{
ACHALASIA IN THE ELDERLY PATIENT: a comparative study
}

\author{
Rosana B. SCHECHTER, Eponina M. O. LEMME, Paula NOVAIS and Beatriz BICCAS
}

\begin{abstract}
Context - Achalasia is a primary esophageal motor disorder secondary to the degeneration of ganglion cells of the inhibitory intramural myenteric plexus. It affects both sexes similarly and has two peaks of incidence, one in the $3 \mathrm{rd}$ to 4 th decades of life and the other after 60 years of age. The effect of age on esophageal motility of patients with achalasia is not well known. Studies have shown that healthy older people, when compared to the young, have: a) a lower number of ganglion cells in the intramural myenteric plexus; b) a reduced normal relaxation of the lower esophageal sphincter; and c) a reduced esophageal peristalsis. Thus, as both age and achalasia can produce comparable degenerative changes in the intramural myenteric plexus, it is possible that advanced age could be an important factor in enhancing the clinical and manometric abnormalities commonly found in patients with achalasia. Objectives - To compare the clinical, radiological and manometric findings in young as compared to elderly ( $>60$ years old) achalasia patients. Methods - A retrospective study of a group of patients with untreated achalasia separated into young and elderly patients. Demographic, clinical, serology for Chagas' disease, radiological and manometric data were compared between these groups. The level of significance was $P<0.05$. Results - The study included 105 patients, 52 young ( $25 \mathrm{M} / 27 \mathrm{~F}$, mean age 40 years old) and 53 elderly (21 M/32 F, mean age 70 years old). The elderly group had a higher prevalence of Chagas' disease $(P=0.004)$ and a lower pressure of the lower esophageal sphincter $[26.4 \mathrm{~mm} \mathrm{Hg}$ vs $31.9 \mathrm{~mm} \mathrm{Hg}] P=0.001$, a difference that persisted when analyzed only elderly and young patients with idiopathic achalasia. Younger patients had a higher prevalence of heartburn $(P=0.001)$ and chest pain $(P=0.012)$ than the elderly. Conclusion - Elderly patients with achalasia had a lower esophageal sphincter pressure than the young, even when we excluded patients with Chagas' disease but, as a group, they were less symptomatic.
\end{abstract}

HEADINGS - Esophageal achalasia. Aged. Manometry.

\section{INTRODUCTION}

Achalasia is a primary esophageal motor disorder associated to the loss of ganglion cells in the intramural myenteric plexus. The manometric findings are the incomplete relaxation of the lower esophageal sphincter (LES) and aperistalsis of the esophageal body. Achalasia affects both sexes equally and there are two peaks of incidence: the first in the 3rd to 4th decades and a second after 60 years of age ${ }^{(2)}$. Life expectancy has increased significantly over the past 15 years and it is estimated that the world population aged over 65 will double over the next 40 years $^{(1,7)}$. Moreover, it is known that with advancing age there is a decrease in function in several body organs, and among the several changes observed, motility of

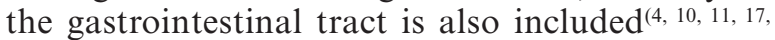
${ }^{19)}$. Since the 1960 's a few studies have investigated the effect of age on esophageal motility. Alterations demonstrated in older individuals include a reduction in amplitude of esophageal contraction, reduction the pressure of the upper and lower sphincters, as well as in the relaxation of the lower esophageal sphincter ${ }^{(3)}$ 9, 12, 13, 17). Autopsy studies have also shown that the elderly had a significant and asymptomatic reduction in the number of ganglion cells in the esophageal myenteric plexus ${ }^{(7,21)}$. These findings suggest that in elderly people asymptomatic, manometric findings may look like those of patients with achalasia. It remains to be studied whether there is an interaction between these two conditions (age and achalasia). Despite the relevance of the doubt, few authors have investigated the effect of age on esophageal motility in patients with achalasia, and this is what motivated the present study.

\section{METHODS}

This is a retrospective study of patients who received the manometric diagnosis of achalasia. This consisted of aperistalsis of the esophageal body, reflected in simultaneous contractions or absence of contraction with amplitude $<15 \mathrm{~mm} \mathrm{Hg}$ and absent or incomplete relaxation of lower esophageal sphincter. We analyzed 105 consecutive untreated achalasia patients in the last 5 years, 52 younger $-<60$ years old ( $25 \mathrm{M} / 27 \mathrm{~F}, 18-59$ years old, mean age 40 years old) and 53 elderly age $>60(21 \mathrm{M} / 32 \mathrm{~F}, 60-84$ years old, mean age 70 years old). These patients had never been treated. Their charts, forms and laboratory tests of

Study accomplished in the Esophageal Unit, Serviço de Gastroenterologia, Hospital Universitário Clementino Fraga Filho, Rio de Janeiro, RJ, Brazil.

Correspondence: Dr. Rosana B. Schechter - Rua Raul Pompéia, 24 - apt. 603 - Copacabana - 22080-000 - Rio de Janeiro, RJ, Brasil. E-mail: rsbihari@yahoo.com.br 
gastrointestinal motility were reviewed, by a single observer. The following data were available and were evaluated by the same observer: 1) demographic and epidemiological data (age, sex, serology for Chagas' disease); 2) clinical manifestations (dysphagia, regurgitation, chest pain, heartburn, weight loss, average time of symptoms); 3) degree of megaesophagus on barium swallow; 4) resting pressure and the characteristics of relaxation of the LES and the contraction amplitude of the distal esophageal body. Is noteworthy that collection of epidemiological and clinical, and all tests were made by professional Unit of Esophagus, Universidade Federal do Rio de Janeiro, RJ, Brazil.

\section{Barium swallow}

In assessing the degree of esophageal dilation we used the Ferreira-Santos classification $^{(8)}$, as follows: Grade I for those who had esophageal diameter of less than $4 \mathrm{~cm}$; Grade II for those with an esophageal diameter between 4 and $7 \mathrm{~cm}$; Grade III when the esophageal diameter was bigger than 7 $\mathrm{cm}$; and Grade IV for those with the esophageal diameter greater than $7 \mathrm{~cm}$, with tortuosity of the body. We considered patients with grades 2, 3 and 4 as having megaesophagus.

\section{Manometry}

We used a polyvinyl catheter $4.5 \mathrm{~mm}$ in diameter with eight lumens, perfused by an infusion pump to a constant flow of $0.6 \mathrm{~mL} / \mathrm{min}$. The four distal catheter orifices were in the same level in radial disposition and the other four were situated $5 \mathrm{~cm}$ proximally to the former. Their distal openings were linked to external pressure transducers. The pressures registered by the transducers were recorded by a polygraph (PC Polygraf VIII, Synectics Medical, Sweden or Alacer, São Paulo, SP, Brazil) and, after its conversion to digital images, transferred to a microcomputer, where they were displayed in real time. Patients were instructed to fast for 4 hours before the test. After topical anesthesia of the nostrils with xylocaine gel $2 \%$, the catheter was introduced into the stomach. The test was initiated by employing the four distal channels in distal disposition and a slow withdrawal technique to study the LES. The relaxation was observed after six swallows of water. Esophageal body recordings were done, by positioning the four proximal opening 3, 8, 13 and $18 \mathrm{~cm}$ above the LES upper limit. Ten swallows of 3 to 5 $\mathrm{mL}$ of water every 20 seconds were performed. In reviewing the tests, we evaluated: 1. the LES resting pressure, which was the average of the peak expiratory pressures measured in each of the four radial channels; 2 . the LES relaxation, that was complete if the nadir pressure was below $8 \mathrm{~mm} \mathrm{Hg}$ after the water swallow, incomplete if it was above $8 \mathrm{~mm} \mathrm{Hg}$ and short-lived if it lasted less than 6 seconds; 3 . the average amplitude of 10 simultaneous peristaltic contractions observed in the distal two channels (C6 and C7), that is, 3 and $8 \mathrm{~cm}$ above the LES.

This study was not submitted for approval by the ethics and research committee (ERC) of our institution since when it was done was not necessary in our institution for submission to ERC retrospective studies.

\section{Statistical analysis}

To compare the variables of sex, presence of Chagas' disease and symptoms, we used the chi-square, while for the other variables we used the $t$-test. Significance was considered below the $5 \%$ level.

\section{RESULTS}

Table 1 shows the demographic and epidemiological data. It was found that the elderly group had a higher prevalence of Chagas' disease $(P=0.048)$. Among the 52 younger patients $42(80 \%)$ were diagnosed as idiopathic achalasia and $10(20 \%)$ as chagasic achalasia. Among the 53 elderly patients $33(62 \%)$ had idiopathic achalasia and $20(38 \%)$ had chagasic achalasia. Table 2 analyzes the clinical manifestations of disease (dysphagia, regurgitation, chest pain, heartburn, weight loss and average duration of symptoms). We found that younger patients had heartburn $(P=0.001)$ and chest pain $(P=0.012)$ significantly more often than the elderly.

TABLE 1. Epidemiological data in groups with achalasia $(n=105)$

\begin{tabular}{lccc}
\hline & $\begin{array}{c}\text { Group I - younger } \\
(<60 \text { anos })\end{array}$ & $\begin{array}{c}\text { Group II - elderly } \\
(>60 \text { anos })\end{array}$ & P value \\
\hline $\begin{array}{l}\text { Total } \\
(\mathrm{n}=105)\end{array}$ & 52 & 53 & \\
Average age & 42 years $(18-59) \pm$ & 69 years $(60-84)$ & NS \\
& 11,34 & $\pm 6,78$ & NS \\
Sex & $25 \mathrm{M} / 27 \mathrm{~W}$ & $21 \mathrm{M} / 32 \mathrm{~W}$ & \\
$\begin{array}{l}\text { (men/women) } \\
\text { Chagas' } \\
\text { serology }\end{array}$ & $20 \%$ & $38 \%$ & $P=0.048$ \\
\hline
\end{tabular}

TABLE 2. Time of symptoms and clinical manifestations in groups with achalasia $(\mathrm{n}=105)$

\begin{tabular}{lccc}
\hline & $\begin{array}{c}\text { Group I - younger } \\
(\mathbf{n}=52)\end{array}$ & $\begin{array}{c}\text { Group II - elderly } \\
(\mathbf{n}=53)\end{array}$ & P value \\
\hline Dysphagia & $100 \%(52)$ & $96 \%(51)$ & NS \\
Regurgitation & $86 \%(49)$ & $72 \%(37)$ & NS \\
Heartburn & $56 \%(29)$ & $32 \%(17)$ & $P=0.001$ \\
Chest pain & $44 \%(23)$ & $23 \%(12)$ & $P=0.012$ \\
Weight loss & $79 \%(41)$ & $68 \%(35)$ & NS \\
Average duration & 4 years & 7 years & NS \\
of symptoms & & & \\
\hline
\end{tabular}

Table 3 assesses the radiological findings (grade of megaesophagus). We did not observe any difference between younger and older patients. Among the elderly $81 \%$ had megaesophagus (grade II-IV) and $68 \%$ of younger patients had dilation of the organ, and that had no statistical significance.

In Table 4 we see the manometric findings. We observed that elderly patients $(\mathrm{n}=53)$ had lower LES pressure [26.4 $\mathrm{mm} \mathrm{Hg}$ vs $31.9 \mathrm{~mm} \mathrm{Hg]}(P=0.001)$ than the young. This statistical difference $(<$ lower esophageal sphincter pressure 
(LESP) in the elderly) persisted even when analyzing only patients with idiopathic achalasia. The LES pressure of patients with idiopathic achalasia in elderly $(\mathrm{n}=33)$ and young $(\mathrm{n}=42)$ groups were $26.8 \mathrm{~mm} \mathrm{Hg}$ and $30.9 \mathrm{~mm} \mathrm{Hg}$ respectively $(P=0.001)$.

TABLE 3. Radiology in groups with achalasia $(\mathrm{n}=105)$

\begin{tabular}{lccc}
\hline & $\begin{array}{c}\text { Group I - younger } \\
(\mathbf{n}=52)\end{array}$ & $\begin{array}{c}\text { Group II - elderly } \\
(\mathbf{n}=53)\end{array}$ & $\boldsymbol{P}$ value \\
\hline$\%$ grade I & $31 \%(16)$ & $21 \%(11)$ & NS \\
$\%$ grade II & $53 \%(28)$ & $53 \%(28)$ & NS \\
$\%$ grade III & $13 \%(7)$ & $25 \%(13)$ & NS \\
$\%$ grade IV & $2 \%(1)$ & $3 \%(2)$ & NS \\
$\%$ Megaesophagus & $68 \%(36)$ & $81 \%(43)$ & NS \\
(grade II-IV) & & & \\
\hline
\end{tabular}

TABLE 4. Manometric findings in groups with achalasia $(\mathrm{n}=105)$

\begin{tabular}{lccc}
\hline & $\begin{array}{c}\text { Grupo I - younger } \\
(\mathbf{n}=52)\end{array}$ & $\begin{array}{c}\text { Grupo II - elderly } \\
(\mathbf{n}=53)\end{array}$ & $\boldsymbol{P}$ value \\
\hline LESP average & $\begin{array}{c}31,9 \mathrm{~mm} \mathrm{Hg} \\
\pm 12,60\end{array}$ & $\begin{array}{c}26,4 \mathrm{~mm} \mathrm{Hg} \\
\pm 10,38\end{array}$ & $P=0.001$ \\
& $20 \%(10)$ & $23 \%(12)$ & $\mathrm{NS}$ \\
$\begin{array}{l}\text { \% normal } \\
\text { relaxation }\end{array}$ & $36 \%(19)$ & $44 \%(23)$ & $\mathrm{NS}$ \\
$\begin{array}{l}\% \text { short } / \\
\text { incomplete } \\
\text { relaxation } \\
\% \text { absent } \\
\text { relaxation }\end{array}$ & $44 \%(23)$ & $33 \%(17)$ & $\mathrm{NS}$ \\
$\begin{array}{l}\text { Average wave } \\
\text { amplitude of in } \\
\text { distal body }\end{array}$ & $25,4 \mathrm{~mm} \mathrm{Hg}$ & $27,7 \mathrm{~mm} \mathrm{Hg}$ & $\mathrm{NS}$ \\
\hline
\end{tabular}

LESP $=$ lower esophageal sphincter pressure

\section{DISCUSSION}

As mentioned earlier, the elderly population is increasing significantly throughout the world. Estimated that the world population aged over 65 will double over the next 40 years ${ }^{(1,}$ 7). Moreover, it is known that with advancing age there is a decrease in function in several body organs, and among the several changes observed, motility of the gastrointestinal tract is also included ${ }^{(4,9,10,11,17,19)}$. It has been shown manometric findings similar to those observed in patients with achalasia (decrease in distal esophageal amplitude and complete relaxation of LES) in asymptomatic elderly people with no comorbidity $(12,13,17,20)$.

A few studies available since the 1960's have been investigating the effect of age on esophageal motility. A study done in nonagenarians ${ }^{(19)}$ demonstrated failure in driving a peristaltic wave and to elicit repetitive simultaneous contractions in the esophagus. However, the subjects had several comorbidities such as diabetes mellitus and neurological diseases, which could influence the results. In the 70 's, another study done in healthy patients aged 70 to 87 years old showed lower amplitude of esophageal contraction waves in individuals over 80 years when compared to younger people ${ }^{(12)}$.

More recently, necropsy studies have shown a significant reduction in the number of ganglion cells in the myenteric plexus $^{(7,21)}$. Other studies have shown that elderly patients presented with lower amplitude of contractions in the distal esophagus and lower number of complete relaxation of the $\operatorname{LES}^{(12,13,20)}$.

Recent studies in the elderly show that both the sensory function, and visceral perception were significantly decreased with advanced age ${ }^{(15,17,18,22)}$. Despite all these findings, few studies were done to investigate the effect of age on esophageal motility of patients with achalasia. Clouse et al ${ }^{(4)}$ conducted a study comparing younger with older patients with idiopathic achalasia and the only difference observed was a lower residual pressure of the LES in the elderly over 70 . No changes in the amplitude of esophageal contraction was seen in these patients. The present study compared the demographic, epidemiological, clinical, radiological and manometric findings in two groups of patients with achalasia, an elderly group ( $>60$ years old) and a younger group $(<60$ years old). We found a higher prevalence of Chagas' disease among the elderly. The city of Rio de Janeiro is not an endemic area for Chagas' disease and patients with this disease are from known endemic places, who migrate into this city or come here seeking treatment.

We know that in Southern and Southeastern Brazil, the majority of patients who are in monitoring in hospitals are old and chronic. Thus, the age group of patients with Chagas' disease in follow-up is increasing and only occasionally gets a new case in patients younger than 50 years. It is therefore justified the finding of higher prevalence of Chagas' disease in the elderly.

There was no significant difference in the prevalence of different degrees of megaesophagus. However, it is important to note that more patients among the elderly had megaesophagus $81 \%$ vs $68 \%$, noting also that the duration of disease was longer than that in the younger group $(7 \mathrm{x} 4$ years), although not statistically different. Moreover, when comparing the degree of dilation of the esophagus and LES pressure did not find significant differences, both within and among groups of megaesophagus (II-IV).

A lower LES pressure was also observed in the elderly. The literature has shown that patients with chagasic achalasia present with LES pressures lower than those with idiopathic achalasia $^{(5,6,14,16)}$. This fact is ascribed to the impairment of inhibitory and excitatory innervation in the former, while that observed in idiopathic achalasia, was only present in the inhibitory pathways ${ }^{(5,6)}$. These findings are similar to those found by Dantas et al. ${ }^{(5)}$. In their study they found that patients with Chagas' disease had a tendency of showing lower LES pressure with advancing age, unlike normal subjects and patients with progressive systemic sclerosis, where the LES pressure does not change with age. The authors suggest that this difference could be linked to factors such as reduction in number of neurons in the intramural plexus, observed in the elderly associated with alterations seen in Chagas' 
disease such as loss of cholinergic excitatory innervation and hyposensitivity to gastrin. In this study, the lower esophageal sphincter pressure found among the elderly could be related to higher prevalence of Chagas' disease. However, even when patients with Chagas' disease were excluded from the statistical analysis, and comparison was carried out between patients with the idiopathic form only, that difference was still found, suggesting that it can be attributed to age.

It is noteworthy also that even when we use only the extremes of ages - young <30 years (18-30th) and elderly $>75$ years (75-84th) the difference in LESP are still found, and of $34.1 \mathrm{~mm} \mathrm{Hg}$ for the young and $24.70 \mathrm{~mm} \mathrm{Hg}$ for the elderly $(P=0.001)$. In our study younger people were more symptomatic than the elderly. It has been demonstrated ${ }^{15,17}$, ${ }^{18,22)}$ that with age there is loss of the sensory function of the esophagus, with lower perception of symptoms. Some studies have confirmed this finding by means of esophageal balloon distention. Healthy elderly ( $>65)$ and younger asymptomatic people, were submitted to distension of a balloon inside the esophagus. It was shown that among the elderly greater distension of the balloon was needed to elicit pain ${ }^{(15,22)}$. The authors wonder whether there was a decrease in perception of visceral pain related to age. Maybe the same applies to our group of elderly patients having less symptoms.

Importantly, even with all the results, more studies are needed, so we can clarify unequivocally the relationship between age and esophageal function. To make this possible it is necessary to perform prospective, well controlled, with close monitoring of exams, in addition to larger sample of patients studied. Furthermore, the implementation of multicenter studies could strengthen the findings from each research center alone, and strengthen the significance of such findings. Thus, only with more research we approach the real role of age on esophageal function.

\section{CONCLUSION}

Elderly patients with achalasia showed a lower LES pressure than the younger, a finding that persisted even when we excluded patients with chagasic achalasia. Younger patients were more symptomatic, and we question whether the elderly had less perception of symptoms than the young. More studies are needed so that we can safely say the role of age on esophageal function.

\section{ACKNOWLEDGMENTS}

We thank Prof. Mauricio de Pinho Gama, from Scientific Investigation Commitee from Clementino Fraga Filho University Hospital, Federal University of Rio de janeiro by the statistical analysis and Dr. Felix R. Zyngier M.D., M.Sc for reviewing and helping with the translation of this study.

Schechter RB, Lemme EMO, Novais P, Biccas B. Acalásia no idoso - um estudo comparativo. Arq Gastroenterol. 2011;48(1):19-23.

RESUMO - Contexto - Acalásia é um distúrbio motor primário do esôfago, secundário à degeneração das células ganglionares do plexo mioentérico inibitório intramural. Afeta ambos os sexos da mesma forma e tem dois picos de incidência: um na $3^{\text {a }}$ e $4^{\text {a }}$ décadas de vida e outro após os 60 anos de idade. O efeito da idade na motilidade esofagiana em pacientes com acalásia não é bem conhecido. Estudos têm demonstrado que os idosos saudáveis quando comparados aos jovens apresentam: a) menor número de células ganglionares no plexo mioentérico intramural, b) redução no número de relaxamentos normais do esfíncter esofagiano inferior, e c) redução do peristaltismo esofagiano. Assim, se tanto a idade quanto a acalásia podem acarretar alterações degenerativas do plexo mioentérico intramural, é possível que a idade avançada possa ser fator importante no aumento das anormalidades clínicas e manométricas, comumente encontradas nos pacientes com acalásia. Objetivos - Comparar os achados clínicos, radiológicos e manométricos dos pacientes jovens com acalásia (<60 anos), em relação aos pacientes idosos (>60 anos). Métodos - Foi realizado estudo retrospectivo de um grupo de pacientes com acalásia não tratada, separando-os em pacientes jovens e idosos. Dados demográficos, clínicos, de sorologia para doença de Chagas, radiológicos e manométricos foram comparados entre os dois grupos. O nível de significância considerado foi $P<0.05$. Resultados - O estudo incluiu 105 pacientes, 52 jovens ( $25 \mathrm{H} / 27 \mathrm{M}$, média de idade de 40 anos) e 53 idosos ( $21 \mathrm{H}, 32 \mathrm{M}$, média de idade de 70 anos). O grupo idoso apresentou elevada prevalência de doença de Chagas $(P=0.004)$ e menor pressão do esfíncter esofagiano inferior [26,4 $\mathrm{mm} \mathrm{Hg} \mathrm{x} 31,9 \mathrm{~mm} \mathrm{Hg}) P=0.001$, diferença esta que persistiu mesmo quando se analisou apenas os pacientes idosos e jovens com acalásia idiopática. Os pacientes jovens apresentaram elevada prevalência de pirose $(P=0.001)$ e dor torácica $(P=0.012)$, quando comparados aos idosos. Conclusão - Os pacientes idosos com acalásia apresentaram pressão do esfíncter esofagiano inferior mais baixa do que os jovens, mesmo quando excluídos com acalásia chagásica, entretanto como grupo eles foram menos sintomáticos.

DESCRITORES - Acalasia esofágica. Idoso. Manometria.

\section{REFERENCES}

1. Blechman MB, Gelb AM. Aging and gastrointestinal phisiology. Clin Geriatr Med. 1999;15:429-38

2. Castell DO. Esophageal disorders in the elderly. Gastroenterol Clin North Am. 1990; 19:235-54.

3. Castell JA, Dalton CB, Castell DO. On-line computer analysis of the human lower esophageal sphincter relaxation. Am J Physiol. 1988; 255:g794-9.
4. Clouse RE, Abramson BK, Todorczuk JR. Achalasia in the elderly: effects of aging on clinical presentation and outcome. Dig Dis Sci. 1991;36:225-8.

5. Dantas RO, Lôbo CJN, Ferrioli E, Matsuda NM. Influence of age on lower esophageal sphincter pressure. Arq Gastroenterol. 1992;29:39-42.

6. Dantas RO, Deghaide NH, Donadi EA. Esophageal motility of patients with Chagas' disease and idiopathic achalasia. Dig Dis Sci. 2001;46:1200-6.

7. Eckardt VF, LeCompte PM. Esophageal ganglia and smooth muscle in the elderly. Am J Dig Dis. 1978;23:443-8. 
8. Ferreira-Santos R. Aperistalsis of the esophagus and colon (megaesophagus and megacolon) etiologically related to Chagas' disease. Am J Dig Dis. 1961;6:700-2.

9. Ferrioli E, Dantas RO, Oliveira RB, Braga FJ. The influence of aging on esophageal motility after ingestion of liquids with different viscosities. Eur J Gastroenterol Hepatol. 1996;8:793-8.

10. Firth M, Prather CM. Gastrointestinal motility problems in the elderly. Gastroenterology. 2002;122:1688-700.

11. Hazzard WR. Demographic peristalsis: implications of the age wave for gastroenterologists. Gastroenterol Clin North Am. 2001;30:297-311.

12. Hollis BJ, Castell DO. Esophageal function in elderly men: a new look at "presbyesophagus". Ann Intern Med. 1974;80:371-4.

13. Khan TA, Shragge BW, Crispin JS, Lind F. Esophagel motility in the elderly. Am J Dig Dis. 1977;22:1049-54.

14. Köberle F. Chagas' disease and Chagas' syndrome: the pathology of American trypanosomiasis. Adv Parasitol. 1968;6:63-116.

15. Lasch H, Castell DO, Castell JA. Evidence for diminshed visceral pain with aging: studies using graded intraesophageal ballon distension. Am J Physiol. 1997;272:G1-3.
16. Lemme EM, Domingues GR, Pereira VL, Firman CG, Pantoja J. Lower esophageal sphincter pressure in idiopathic achalasia and Chagas disease-related achalasia. Dis Esophagus. 2001;14:232-4.

17. Orr WC, Chen CL. Aging and neural control of the GI tract. IV. Clinical and physiological aspects of gastrointestinal motility and aging. Am J Physio Gastrointest Liver Physiol. 2002;283:G1226-31.

18. Patel R, Rao S. Biochemical and sensory parameters of the human esophagus vary with age. Am J Gastroenterol. 1995;90:1567.

19. Soergel KH, Zboralske FF, Amberg JR.- Presbyesophagus: esophageal motility in nonagenarians. J Clin Invest. 1964;43:1472-9.

20. Szurszewski JH, Holt PR, Schuster M. Proceedings of a workshop entitled "Neuromuscular function and dysfunction of the gastrointestinal tract in aging". Dig Dis Sci. 1989;34:1135-46.

21. Wada MLF. Quantitative study of ganglion neurons of the human esophagus in relation to age. Rev Goiana Med. 1981;27:7-33.

22. Weusten BL, Lam HG, Akkermans LM, Van Berge-Henegouwen GP, Smout AJ Influence of age on cerebral potentials evoked by oesophageal balloon distension in humans. Eu J Clin Invest. 1994;24:627-31. 